\title{
Identification and antioxidant activity of synthetic peptides from phycobiliproteins of Pyropia yezoensis
}

\author{
EUN-YOUNG KIM ${ }^{1}$, YOUN HEE CHOI ${ }^{1,2}$ and TAEK-JEONG NAM ${ }^{1,3}$ \\ ${ }^{1}$ Institute of Fisheries Sciences, Pukyong National University, Busan 46041; \\ ${ }^{2}$ Departments of Marine Bio-Materials and Aquaculture; ${ }^{3}$ Department of Food and Life Science, \\ Pukyong National University, Busan 48513, Republic of Korea
}

Received November 6, 2017; Accepted April 26, 2018

DOI: $10.3892 /$ ijmm.2018.3650

\begin{abstract}
The objective of the present study was to identify peptides, based on active components of the red algae seaweed Pyropia yezoensis, able to inhibit the generation of reactive oxygen species (ROS), which is associated with aging and oxidative activities. Phycobilin, specific to red algae, covalently binds with water-soluble proteins. There are three types of pigment bound proteins, known as phycobiliproteins (PBPs): Phycoerythrin (PE), phycocyanin (PC) and allophycocyanin (APC). In the present study, PBPs reported previously to have antioxidant activities in P.yezoensis were identified and, based on these data, several peptides were synthesized (PBP 1-13) and their inhibition of ROS generation was examined. The existence of PBPs of each type, PE, PC and APC, was established in P. yezoensis and all were analyzed. In addition, PBP 1-2 and 7-9 peptides from PE were synthesized and showed antioxidant activities in HepG2 cells. In HepG2 cells, treatment with PBP2 reduced hydrogen peroxide-mediated oxidative stress and restored the expression of superoxide dismutase (SOD). Furthermore, phosphorylated nuclear factor erythroid-derived 2-like 2 (Nrf2) was elevated by PBP2 treatment. Overall, these results suggested that Nrf2-SOD pathways may be involved in the PBP2-mediated antioxidant effects. Therefore, from the investigations of P.yezoensis, several candidate peptides were identified with promising antioxidant and, potentially, anti-aging properties.
\end{abstract}

\section{Introduction}

Seaweed, including laver, is a standard food consumed in Asian countries, including Korea and Japan. Several studies have reported that seaweed has various bioactive substances with anticancer, antiviral and anticoagulant effects (1-5). The

Correspondence to: Professor Taek-Jeong Nam, Department of Food and Life Science, Pukyong National University, 45 Yongso-ro, Nam-gu, Busan 48513, Republic of Korea

E-mail: namtj@pknu.ac.kr

Key words: Pyropia yezoensis, antioxidant peptides, phycobiliproteins, phycoerythrin, phycocyanin, allophycocyanin majority of studies on seaweed bioactivity have investigated solvent extracts, rather than mono-constituent substances, and there has been limited investigation of seaweed proteins and peptides (6). Previous studies have progressed our understanding of the bioactive components in seaweed, including the partial creation of a seaweed protein database, identification of a seaweed protein that changes according to stress and environment, proteomic investigations on its usefulness as a biomarker, and the development of a DNA marker based on the genomic sequence of the laver Pyropia species (7). However, there remains a paucity of basic information describing the activity and function of the bioactive components of seaweed.

The most prominent characteristic of seaweed is photosynthesis, which occurs in semiautonomous organelles, chloroplasts. Red algae contain a pigment termed phycobilin, which forms a covalent bond with a water-soluble protein. Unlike chlorophyll, a fat-soluble pigment that requires extraction with organic solvents, phycobilin is a water-soluble pigment that can be readily purified (8). Phycobiliproteins (PBPs) are largely divided into three types. The first type is phycoerythrin (PE), a complex between phycoerythrobilin and a protein, which has a scarlet color. The second type is phycocyanin (PC), a complex between phycocyanobilin and a protein, which forms a blue color. The third type is the indigo-blue allophycocyanin (APC), a complex between phycocyanobilin and a protein with a distinct absorption spectrum. These three complexes are all acidic, with isoelectric points of 4.3. Each type of PBP is further divided into subtypes. PE has three subtypes: $\mathrm{B}, \mathrm{R}$ and $\mathrm{C}$; PC has two subtypes: $\mathrm{C}$ and R; and APC has only one subtype. In Pyropia yezoensis, the PBP type depends on its color variation. PBPs have been reported to protect hepatocytes and to have anti-inflammatory and antioxidant effects, indicating their potential application as therapeutic agents $(9,10)$. Previous studies have extracted, refined and functionally analyzed particular PBPs from cyanobacteria and seaweed $(8,10,11,12)$. According to a previous report, it was possible to separate three types of PBPs simultaneously from Lyngbya sp. (13). However, there have been no reports on the separation of PBPs from seaweed and their functional analysis. Therefore, the present study aimed to identify proteins separated from laver, seaweed rich in PBPs, using two-dimensional polyacrylamide gel electrophoresis (2D-PAGE) and to analyze their antioxidant activities. 
Reactive oxygen species (ROS) that are generated in vivo are a major cause of human aging and disease. The generation of ROS leads to disease through toxic effects on cells and tissues. ROS include free radical species, including superoxide anions, hydroxyl radicals and singlet oxygen, in addition to non-radical species, including hydrogen peroxide $\left(\mathrm{H}_{2} \mathrm{O}_{2}\right)$. ROS levels are tightly controlled in the body by antioxidant enzymes, including superoxide dismutase (SOD), catalase (CAT) and glutathione peroxidase (GPx).

The liver is an important tissue responsible for metabolism and the detoxification of nutrients in the human body. Liver injury can be caused by alcohol, viral infection, drug abuse and oxidative stress (14-16). In the present study, HepG2 cells were used to examine the antioxidant function of hepatocytes. HepG2 cells were first reported as hepatocellular carcinoma cells, however, certain genes were confirmed to be more similar to hepatoblastoma in $2009(17,18)$. These cells have been used to investigate liver metabolism, development, oncogenesis (chemocarcinogenesis and mutagenesis), and hepatotoxicity in thousands of cases in previous studies (17,19-26). HepG2 cells are cancer cells, however, they do not differ from normal liver cells in their detoxification and antioxidant mechanism (18). In the present study, the HepG2 cell line was used for the antioxidant function of hepatocytes.

PBPs have a variety of bonds between pigments and proteins, and even the same PBP type can include different phycobilins, with the composition influenced by the environment. As reported previously, PBPs are suggested to have potential antioxidant properties (27). Therefore, the present study aimed to identify PBPs in laver, elucidate their features and evaluate the potential of peptides derived from these PBPs as antioxidant agents.

\section{Materials and methods}

Red algal materials and crude extraction. P. yezoensis was obtained from Myeongji (Busan, Korea) and stored at $-70^{\circ} \mathrm{C}$. The frozen samples were lyophilized and homogenized prior to protein extraction. The crude soluble fraction was extracted with $0.1 \mathrm{M}$ sodium acetate buffer (pH 6.0). Samples of $P$. yezoensis $(1 \mathrm{~g})$ were mixed with $50 \mathrm{ml}$ sodium acetate buffer for $16 \mathrm{~h}$ with continuous shaking at $4^{\circ} \mathrm{C}$, and then filtered through Whatman No. 1 filter paper. The extract was then precipitated with methanol and chloroform (28). Protein material was precipitated to increase the purity and the resulting supernatants were treated with a 2-D Clean-up kit (GE Healthcare Life Sciences, Logan, UT, USA). Protein concentrations were determined using a bicinchoninic acid assay with bovine serum albumin (Thermo Fisher Scientific, Inc., Waltham, MA, USA) as the standard.

Identification of purified proteins. For 2D-PAGE analysis, isoelectric focusing was performed as the first dimension and SDS-PAGE as the second dimension, according to the manufacturer's protocols (GE Healthcare Life Sciences). Protein samples $(150 \mu \mathrm{g})$ containing $0.5 \%$ immobilized $\mathrm{pH}$ gradient (IPG) buffer (pH 4-7) and 5\% bromophenol blue were applied to an immobilized IPG DryStrip (pH 4-7, $13 \mathrm{~cm}$, GE Healthcare Life Sciences) and rehydrated for $16 \mathrm{~h}$ in lysis solution containing $4 \mathrm{M}$ urea, 4\% 3-(3-cholami-dopropyl dimethylammonio) propanesulfonate, $2 \mathrm{M}$ thiourea, $100 \mathrm{mM}$ dithiothreitol and $1 \%$ polyvinylpyrrolidone. Prior to performing the second dimension SDS-PAGE, focused IPG strips were equilibrated for $20 \mathrm{~min}$ in a solution of $50 \mathrm{mM}$ Tris- $\mathrm{HCl}$ (pH 8.8), $6 \mathrm{M}$ urea, $30 \%$ glycerol, $2 \%$ SDS and 1\% DTT, and then for an additional $20 \mathrm{~min}$ in the same solution, but with the DTT replaced with $0.5 \%$ iodoacetamide. The equilibrated strips were positioned on a $15 \%$ polyacrylamide gel $(14 \times 13 \mathrm{~cm}$, $1.5 \mathrm{~mm}$ ) and, following SDS-PAGE the gels were silver-stained. Analysis of the partial amino acid sequences of the soluble proteins was performed using electrospray ionization quadrupole time-of-flight mass spectrometry/mass spectrometry (ESI Q TOF MS/MS), as described previously (29).

Peptide synthesis. The P. yezoensis PBP-derived peptides (PBP 1-13) were synthesized by Peptron (Daejeon, Korea). Purification of the 13 peptides was performed on a C18 column (Shiseido CAPCELL PAK; Shiseido, Tokyo, Japan) attached to a high-performance liquid chromatography apparatus with elution in $0.1 \%$ trifluoroacetic acid and a gradient of 3-70\% acetonitrile, a flow rate of $1 \mathrm{ml} / \mathrm{min}$ and UV detection at $220 \mathrm{~nm}$. The peptide molecular weights, as shown in Table I, were determined by mass analysis (HP 1100 series LC/MSD; Agilent Technologies, Inc., Santa Clara, CA, USA).

Measurements of cell viability and ROS. The HepG2 human hepatoblastoma cell lines were obtained from American Type Culture Collection (Rockville, MD, USA). The cells were cultured at $37^{\circ} \mathrm{C}$ in a humidified $5 \% \mathrm{CO}_{2}, 95 \%$ air equilibrated incubator in modified Eagle's medium (Sigma-Aldrich; Merck KGaA, Darmstadt, Germany) supplemented with heat-inactivated $10 \%$ fetal bovine serum (FBS; HyClone, Logan, UT, USA), $100 \mathrm{U} / \mathrm{ml}$ penicillin and $100 \mu \mathrm{g} / \mathrm{ml}$ streptomycin. The adherent cells were detached with trypsin-EDTA solution and plated at 70-80\% confluence.

Cell viability was measured with fluorescein diacetate (FDA) and propidium iodide (PI), which stain viable cells and dead cells, respectively. The cells were seeded at a density of $1.5 \times 10^{4}$ cells per well in a 96-well plate. PBP 1-13 $(1 \mu \mathrm{g} / \mathrm{ml})$ were added and the cells were treated with $5 \mathrm{mM} \mathrm{H}_{2} \mathrm{O}_{2}$ for $1 \mathrm{~h}$. The cell culture medium was then removed and FDA (at a final concentration of $10 \mu \mathrm{g} / \mathrm{ml}$ ) or PI (at a final concentration of $5 \mu \mathrm{g} / \mathrm{ml}$ ) was added. The cells were incubated at $37^{\circ} \mathrm{C}$ for $30 \mathrm{~min}$. The staining solutions were removed and the samples were washed with phosphate-buffered saline (PBS). In order to determine the experimental concentrations of PBP peptides, a preliminary experiment was performed using $1-100 \mu \mathrm{g} / \mathrm{ml}$ of peptides with FDA and PI. The subsequent experiments were performed using the range of 0.001-0.01-0.1-1 $\mu \mathrm{g} / \mathrm{ml}$, which showed the concentration-dependent changes and suitability in measurement (data not shown).

Inhibition of ROS production by PBP 1-13 was evaluated in the HepG2 cells using a cell permeable probe, 2',7'-dichlorofluorescein diacetate (DCF-DA). The cells were seeded onto 96-well plates $\left(1.5 \times 10^{4}\right.$ cells per well), grown until confluence and pre-incubated with $50 \mu \mathrm{M}$ DCF-DA for $1 \mathrm{~h}$ at $37^{\circ} \mathrm{C}$ in the dark. Following washing with PBS away excess probe, the cells were treated with PBS or PBP 1-13 $(1 \mu \mathrm{g} / \mathrm{ml})$ in the presence or absence of $5 \mathrm{mM} \mathrm{H}_{2} \mathrm{O}_{2}$, for $1 \mathrm{~h}$. Ascorbic acid $(1 \mu \mathrm{g} / \mathrm{ml})$ was used as an antioxidant control. 


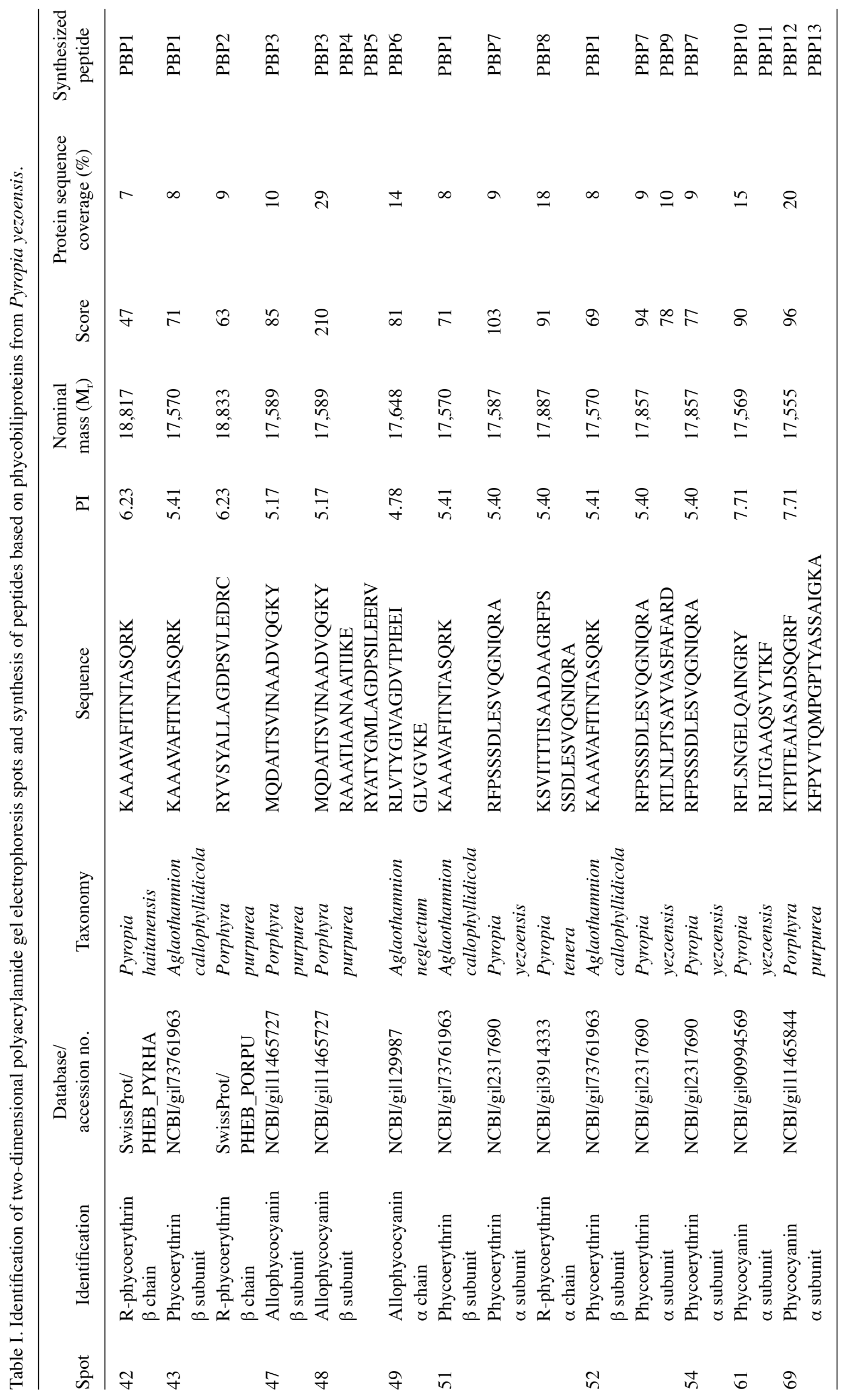


Fluorescence was measured using a FilterMax F5 Multi-Mode microplate reader (Molecular Devices LLC, Sunnyvale, CA, USA) and an Epi-fluorescence microscope (Nikon Corporation, Tokyo, Japan) with the following settings: Excitation $485 \mathrm{~nm}$ and emission $535 \mathrm{~nm}$ for FDA and DCF-DA, and excitation $535 \mathrm{~nm}$ and emission $615 \mathrm{~nm}$ for PI. The viability and ROS production of the synthetic peptide-treated cells were calculated as a percentage of that in the untreated control cells.

Quantitative analysis of living and dead cells according to PBP2 concentrations were performed according to the manufacturer's protocol of the FITC Annexin V Apoptosis Detection Kit I (BD Biosciences, Franklin Lakes, NJ, USA) and measured with a Muse ${ }^{\mathrm{TM}}$ Cell Analyzer (EMD Millipore, Billerica, MA, USA). To measure the number of stained cells, ImageJ software (version 1.41; National Institutes of Health, Bethesda, MD, USA) was used alongside Cell Counting Macro 1 [version 1.0; developed by Kurt De Vos (Academic Neurology, University of Sheffield, Shefield, UK) and used by the GNU General Public License, https:/github. com/grishagin/CellCounting/archive/master.zip].

The cells were seeded at a density of $1.5 \times 10^{4}$ cells per well in a 96-well plate. PBP2 $(1 \mu \mathrm{g} / \mathrm{ml})$ was added and the cells were treated with $5 \mathrm{mM} \mathrm{H}_{2} \mathrm{O}_{2}$ for $1 \mathrm{~h}$. The cell culture medium was then removed, and the cells were washed with PBS. The cells were then stained with Annexin V and PI for $15 \mathrm{~min}$ in the dark at $25^{\circ} \mathrm{C}$.

Western blot analysis. Whole cell extracts for the detection of SOD, CAT and GPx by immunoblotting were isolated from the $\mathrm{H}_{2} \mathrm{O}_{2}$-treated HepG2 cells with or without PBP 1-13 peptide treatment. Separation of nuclei was performed using the Nuclei EZ Prep nuclear isolation kit (Sigma-Aldrich; Merck KGaA, Darmstadt, Germany) according to the manufacturer's protocols. Protein concentration was determined by bicinchoninic acid assay. The cell lysates $(30 \mu \mathrm{g})$ and nuclei $(20 \mu \mathrm{g})$ were separated by electrophoresis on a $15 \%$ SDS-PAGE gel and transferred onto polyvinylidene difluoride membranes (EMD Millipore) using a semi-dry transfer system. The membranes were blocked with $1 \%$ BSA in TBST buffer $\left(0.1 \%\right.$ Tween 20 in TBS) overnight at $4^{\circ} \mathrm{C}$ and incubated with the following primary antibodies: SOD2 (1:2,000; cat. no. OASE00357; Aviva Systems Biology, San Diego, CA, USA), CAT (1:500; cat. no. OAAB05216; Aviva Systems Biology), GPx1 (1:1,000; cat. no. OAAF05777; Aviva Systems Biology), PCNA (1:1,000; cat. no. sc-56, Santa Cruz Biotechnology, Inc., Heidelberg, Germany), $\beta$-actin (1:1,000; cat.no. sc-47778; Santa Cruz Biotechnology Inc.), nuclear factor erythroid-derived 2-like 2 (Nrf2; 1:1,000; cat. no. sc-722; Santa Cruz Biotechnology, Inc.); p-Nrf2 (1:5,000; cat. no. ab76026; Abcam, Cambridge, UK) in TBST solution containing $1 \%$ BSA for $1 \mathrm{~h}$ at room temperature. Following washing three times with TBST, the membranes were incubated for $1 \mathrm{~h}$ at room temperature with anti-rabbit and anti-mouse secondary antibodies (Thermo Fisher Scientific, Inc.) with horseradish peroxidase and washed with TBST three times. The final detection was performed with enhanced chemiluminescence western blotting reagents (Santa Cruz Biotechnology, Inc.). GeneTools software (version 4.03; Syngene, Cambridge, UK) was used for densitometry.
Statistical analysis. Data are expressed as the mean \pm standard deviation and were evaluated by one-way analysis of variance using the statistical package for social sciences version 10.0 (SPSS, Inc., Chicago, IL, USA). Values were compared with controls using one-way analysis of variance followed by Duncan's multiple range tests. $\mathrm{P}<0.05$ was considered to indicate a statistically significant difference.

\section{Results}

Identification of PBPs. Soluble proteins were extracted from $P$. yezoensis and separated by 2D-PAGE. The soluble proteins were classified by their isoelectric points (pIs) using a strip with a $\mathrm{pH}$ range of 4-7. As shown in Fig. 1, 200 spots were resolved. To characterize PBPs with pI values of 4-6, 60 spots observed between 11 and $25 \mathrm{kDa}$ were analyzed by ESI-Q TOF MS/MS. As a result, 10 spots were identified as PBPs (enclosed with circles in the tetragon in Fig. 1A). As shown in Table I, the identified PBPs were PE (spots 42, 43, 51, 52 and 54), PC (spots 61 and 59) and APC (spots 47, 48 and 49). PE was identified as the $\alpha$-type based on peptide sequences analyzed from spots 51, 52 and 54, RFPSSSDLESVQGNI QRA, RTLNLPTSAYVASFAFARD and KSVITTTISAAD AAGRFPSSSDLESVQGNIQRA; and as the $\beta$-type based on sequences from spots 42, 43 (Fig. 1B and C), 51 and 52, KAA AVAFITNTASQRK and RYVSYALLAGDPSVLEDRC. $\mathrm{PC}$ was identified as the $\alpha$-type with the sequences analyzed from spots 61 and 69, RFLSNGELQAINGRY, RLITGA AQSVYTKF, KTPITEAIASADSQGRF and KFPYVTQMP GPTYASSAIGKA. APC- $\alpha$ was identified by the sequences of spots 47 and 48, MQDAITSVINAADVQGKY, RAAATI AANAATIIKE and RYATYGMLAGDPSILEERV, whereas APC- $\beta$ was identified by the sequence of spot 49 , RLVTYG IVAGDVTPIEEIGLVGVKE.

Cell viabilities and ROS inhibition activities of synthetic peptides. The HepG2 human hepatoblastoma cell line derived from the HepG2 cell line can be used for investigations of xenobiotic metabolism as it maintains the synthesis and secretion of plasma proteins and cell surface receptors, which are specific functions of normal liver parenchymal cells $(18,19)$. This was performed in the present study to confirm the protective effect of PBP peptides on oxidative stress and liver injury induced by the $\mathrm{H}_{2} \mathrm{O}_{2}$ in vitro system. As the liver is central for detoxification in vivo, HepG2 cell line, which is a human liver cell, was used as a target to observe the protective effect of oxidative stress.

The synthetic peptides, listed in Table I, were administered at $1 \mu \mathrm{g} / \mathrm{ml}$ to the HepG2 human liver cells, and their viabilities and ROS inhibition activities were determined. The fluorescent indicator dyes DCF-DA, FAD and PI load readily into guard cells, and their optical properties make them amenable to analysis using a fluorescence spectrophotometer. As shown in Fig. 2A, the number of viable cells was reduced to $47 \%$ by $5 \mathrm{mM} \mathrm{H} \mathrm{O}_{2}$. PBP1, 2 and 7-9 increased the number of viable cells by $23-32 \%$, whereas dead cells stained with PI increased 2.3-fold by $5 \mathrm{mM} \mathrm{H}_{2} \mathrm{O}_{2}$ (Fig. 2B). PBP 1-13 reduced dead cells by $30-143 \%$. In particular, PBP2 decreased to the negative control level. The ratio of viable cells to dead cells was reduced to 0.23 by $5 \mathrm{mM} \mathrm{H}_{2} \mathrm{O}_{2}$, but recovered in the presence 
A
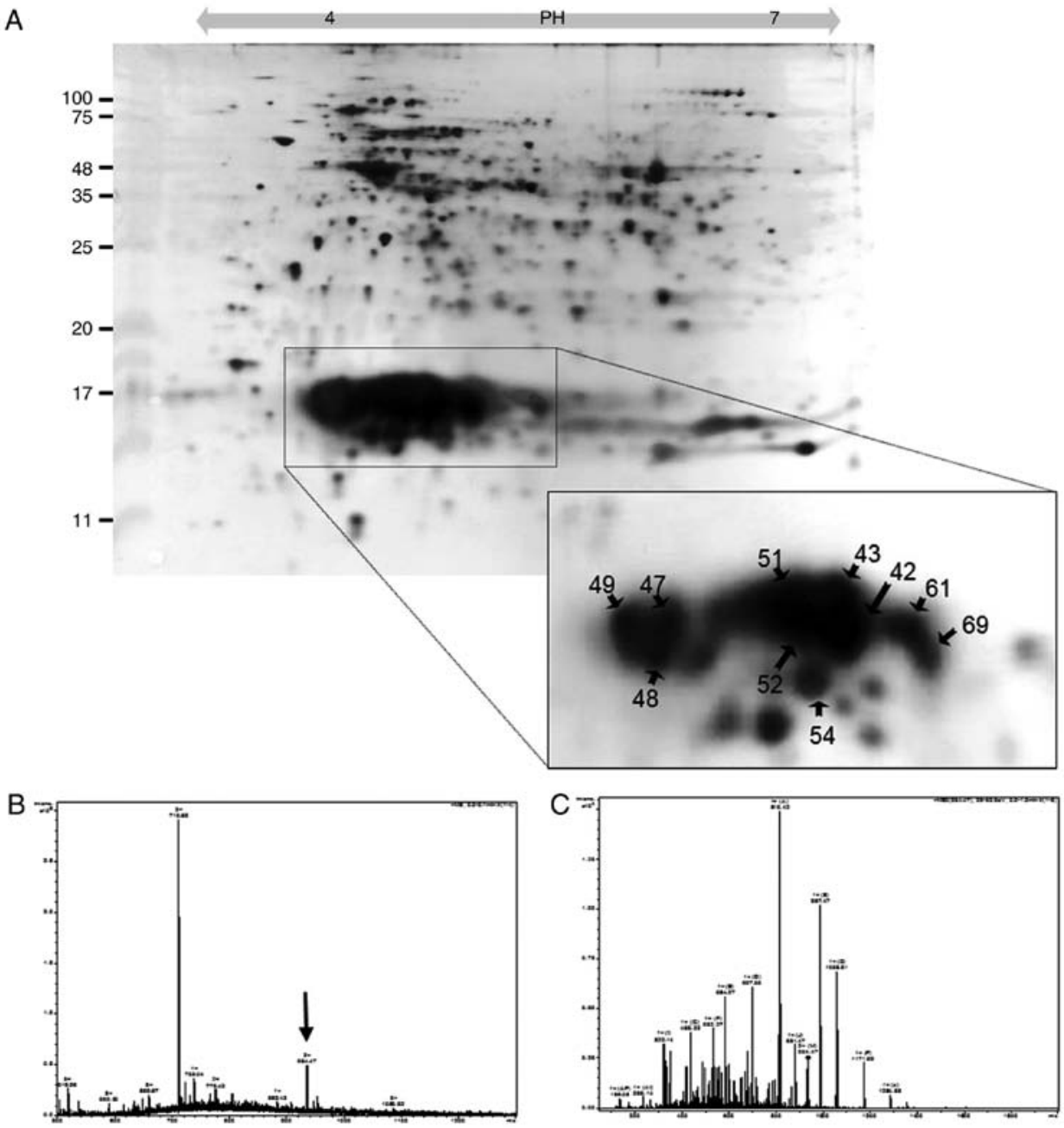

Figure 1. Proteome reference map of P. yezoensis. (A) Isoelectric focusing was performed with a soluble protein extract of P. yezoensis using a 13-cm $\mathrm{pH} 4-7$ immobilized gradient strip, followed by SDS-PAGE on a 12\% acrylamide gel and then visualized by silver staining. The enlarged square indicates the position of the identified protein by ESI Q TOF MS/MS. The numbers refer to the protein identities shown in Table I. (B) ESI Q TOF MS spectrum (arrow: Amino acid sequence analysis by MS/MS) and (C) MS/MS spectrum of spot 43. P. yezoensis, Pyropia yezoensis; ESI Q TOF MS, electrospray ionization quadrupole time-of-flight mass spectrometry.
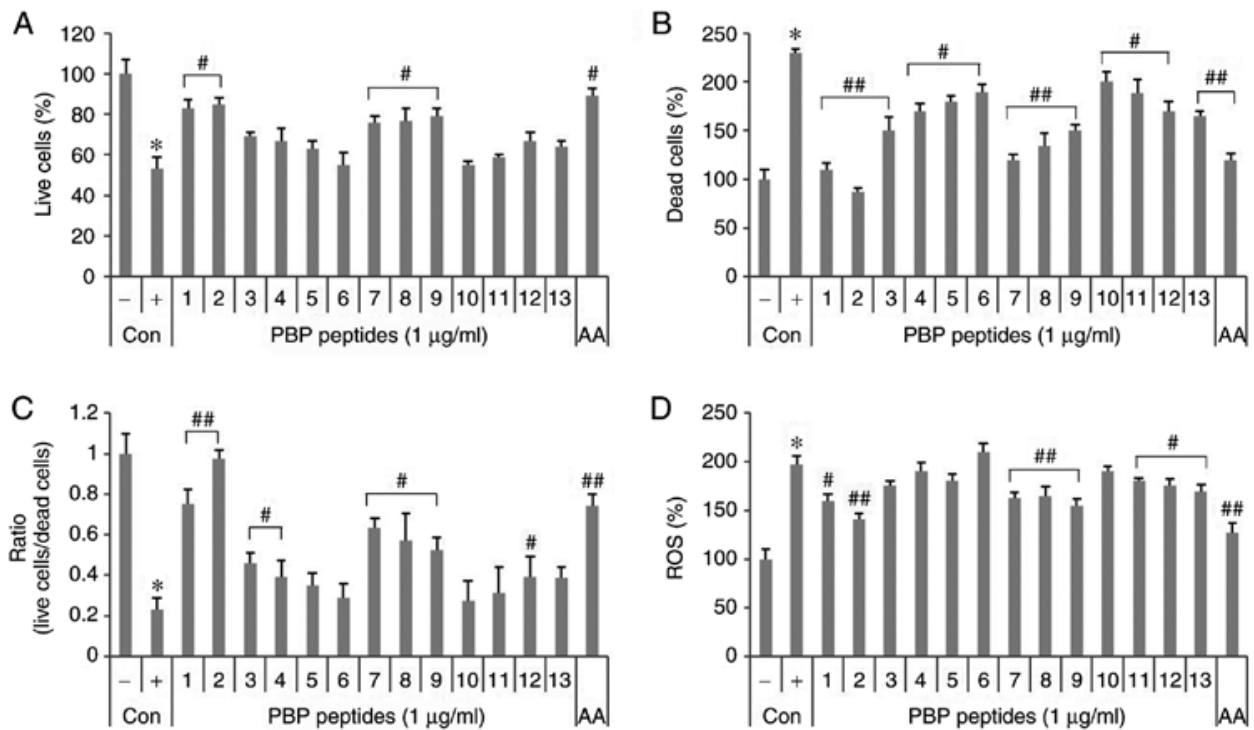

Figure 2. Effects of synthetic PBP peptides in HepG2 cells. Induction of $5 \mathrm{mM} \mathrm{H}_{2} \mathrm{O}_{2}$-induced cell toxicity and the effects of synthetic peptides. Live cells and dead cells were stained with (A) fluorescein diacetate and (B) propidium iodide. (C) Ratio of live cells/dead cells. (D) Effects of the synthetic peptides on the formation of $\mathrm{H}_{2} \mathrm{O}_{2}$-induced ROS. Cells were pretreated with 2',7'-dichlorofluorescin diacetate. Values are expressed as the mean \pm standard deviation ( $\mathrm{n}=3$ ). ${ }^{*} \mathrm{P}<0.05$, vs. untreated control; ${ }^{~} \mathrm{P}<0.05$, vs. $5 \mathrm{mM} \mathrm{H}_{2} \mathrm{O}_{2}$-treated control. ${ }^{\# \prime} \mathrm{P}<0.01$, vs. $5 \mathrm{mM} \mathrm{H}_{2} \mathrm{O}_{2}$-treated control. -, control cells without $5 \mathrm{mM} \mathrm{H} \mathrm{O}_{2}$; +, control cells treated with $5 \mathrm{mM} \mathrm{H}_{2} \mathrm{O}_{2}$; PBP, phycobiliprotein; AA, $1 \mu \mathrm{g} / \mathrm{ml}$ ascorbic acid; $\mathrm{H}_{2} \mathrm{O}_{2}$, hydrogen peroxide; ROS, reactive oxygen species; Con, control. 
A

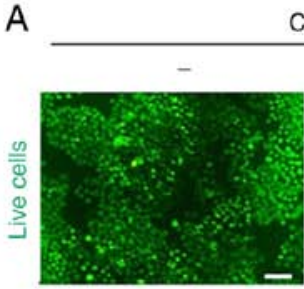

Con
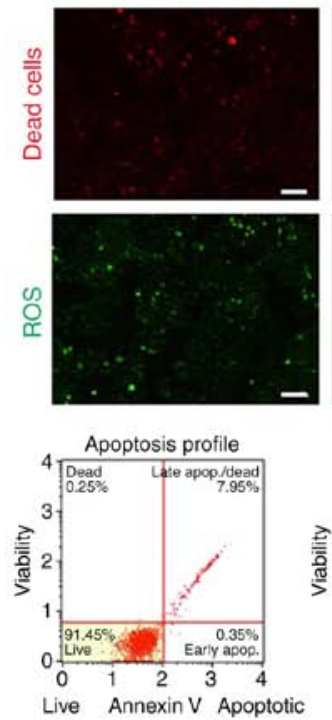
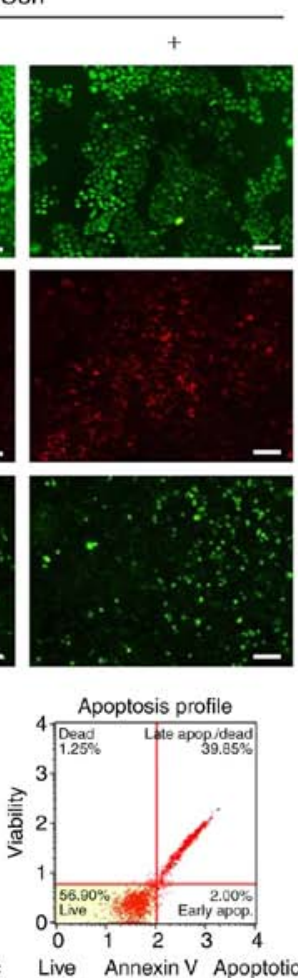
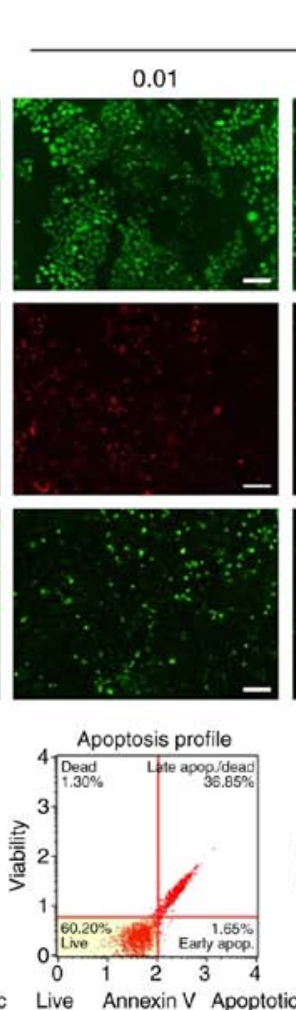

PBP2 $(\mu \mathrm{g} / \mathrm{ml})$
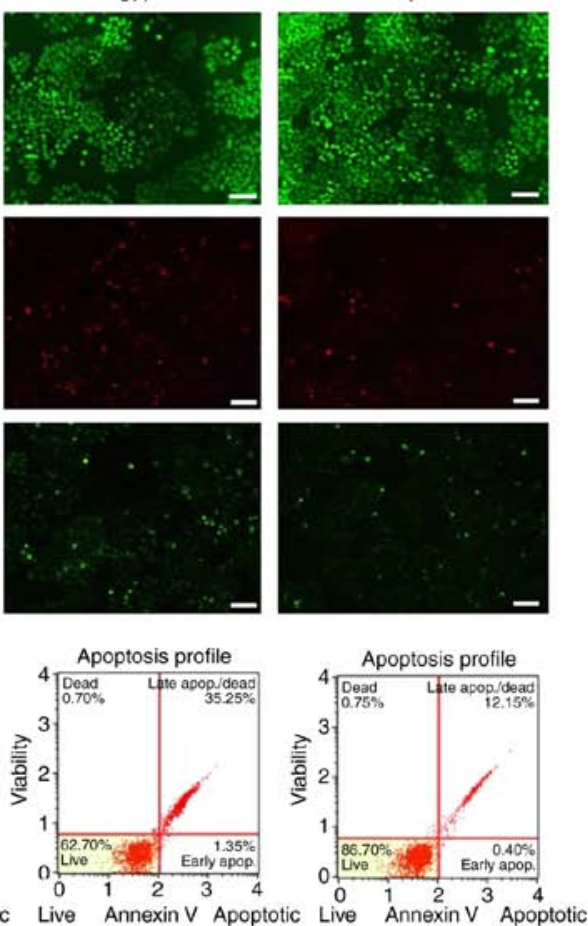

B

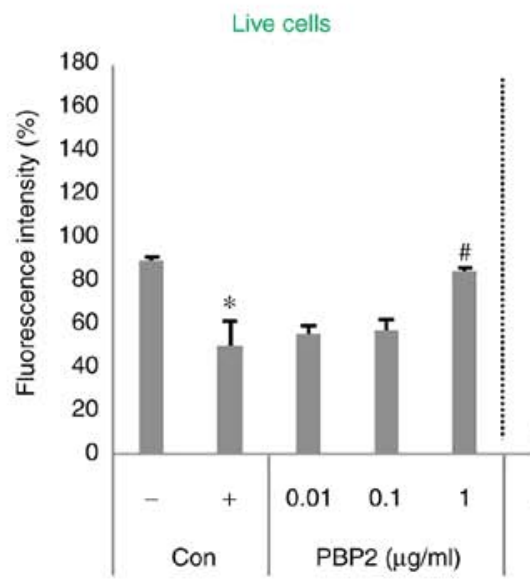

Apoptotic/dead cells

ROS

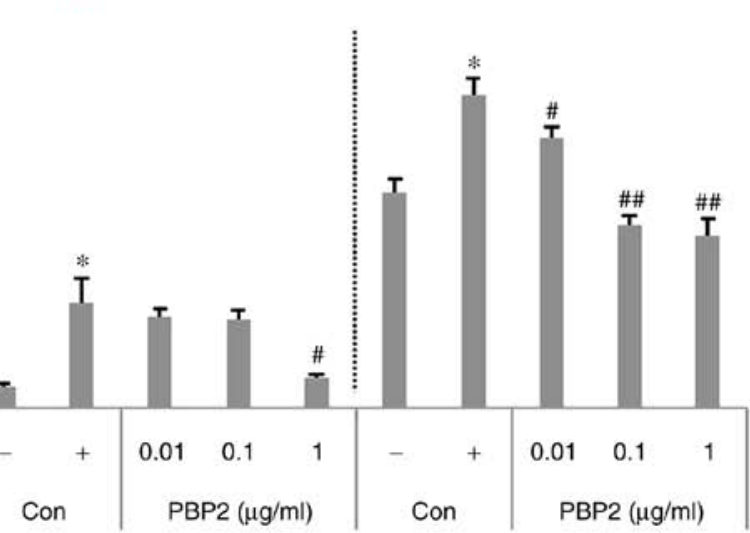

Figure 3. PBP2 resorted $5 \mathrm{mM} \mathrm{H} \mathrm{O}_{2}$-induced oxidative stress in HepG2 cells. (A) Live cells, apoptotic cells, dead cells and ROS were detected by fluorescein diacetate, propidium iodide, Annexin V and 2',7'-dichlorofluorescein diacetate staining. Scale bar=100 $\mu \mathrm{m}$. (B) Fluorescence intensity was analyzed using ImageJ software and the Muse ${ }^{\mathrm{TM}}$ cell analyzer. Values are expressed as the mean \pm standard deviation $(\mathrm{n}=3)$. ${ }^{*} \mathrm{P}<0.05$, vs. untreated control; ${ }^{\#} \mathrm{P}<0.05$, vs. $5 \mathrm{mM} \mathrm{H} \mathrm{O}_{2}$-treated control; ${ }^{\# \#} \mathrm{P}<0.01$, vs. $5 \mathrm{mM} \mathrm{H} \mathrm{O}_{2}$-treated control. -, control cells without $5 \mathrm{mM} \mathrm{H}_{2} \mathrm{O}_{2} ;+$, control cells treated with $5 \mathrm{mM} \mathrm{H} \mathrm{O}_{2}$; $\mathrm{PBP} 2$, phycobiliprotein $2 ; \mathrm{H}_{2} \mathrm{O}_{2}$, hydrogen peroxide; ROS, reactive oxygen species; Con, control.

of PBP1-4, 7-9 and 12 (Fig. 2C). In particular, PBP1-2 led to recovery with a ratio over three times higher than that of the positive control. Treatment with $5 \mathrm{mM} \mathrm{H}_{2} \mathrm{O}_{2}$ increased the production of ROS $\sim 2$-fold compared with that of the negative control (Fig. 2D). PBP 1, 2, 7-9 and 11-13 led to a $17-56 \%$ reduction in the production of ROS compared with that of the positive control. As a result, PBP 1, 2, 7-9 and 12 protected cells from oxidative stress by $\mathrm{H}_{2} \mathrm{O}_{2}$ and exhibited an antioxidative effect.

In particular, PBP2 showed good efficacy in terms of cell survival, prevention of death and inhibition of ROS production compared with $1 \mu \mathrm{g} / \mathrm{ml}$ ascorbic acid, a well-known antioxidant.
Effects of $\mathrm{PBP} 2$ under $\mathrm{H}_{2} \mathrm{O}_{2}$-induced oxidative stress in HepG2 cells. The HepG2 cells were stained with DCF-DA, PI, Annexin V and FDA, and observed with a fluorescence microscope and a fluorescence absorbance spectrophotometer to determine cytoprotective activity and antioxidant activity according to the concentration of PBP2 $(0.001-1 \mu \mathrm{g} / \mathrm{ml})$. The viable cell number decreased in the presence of $5 \mathrm{mM} \mathrm{H}_{2} \mathrm{O}_{2}$, whereas the number of dead cells and ROS increased (Fig. 3A and B). PBP2 at concentrations of $1 \mu \mathrm{g} / \mathrm{ml}$ increased the number of living cells and restored apoptotic cells and dead cells to negative control levels. In addition, $0.1-1 \mu \mathrm{g} / \mathrm{ml}$ PBP2 reduced the production of ROS by $>50 \%$ when compared with that of the positive control. 
A

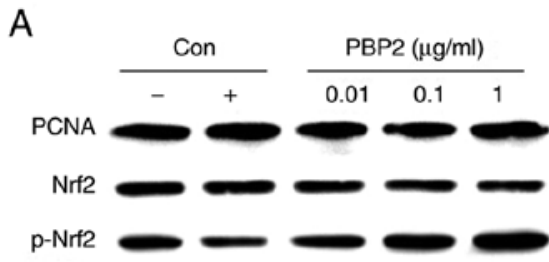

C

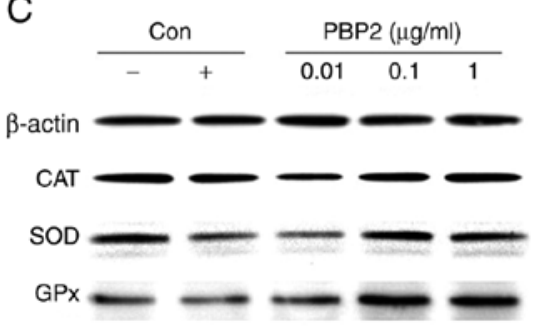

B
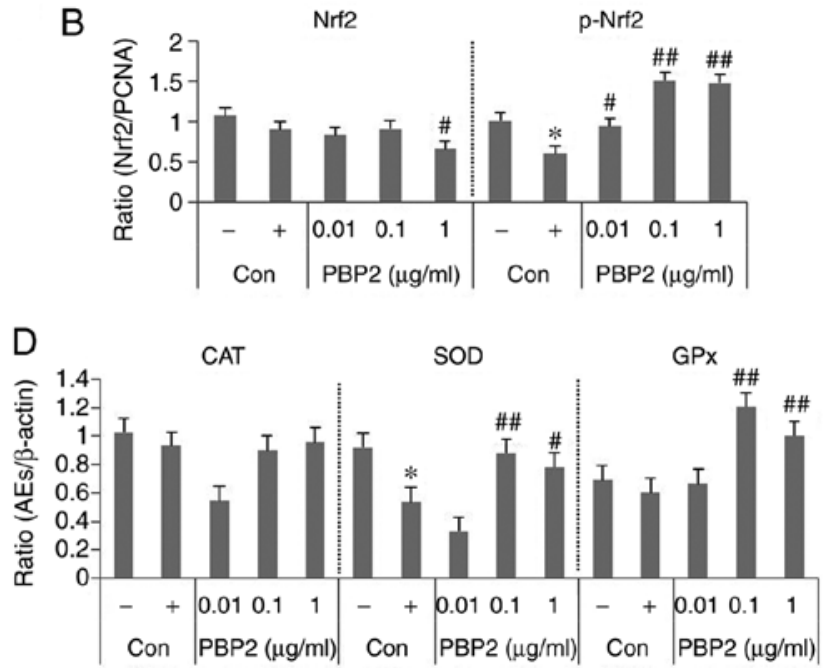

Figure 4. Effects of PBP2 on protein expression levels of CAT, SOD and GPx in $\mathrm{H}_{2} \mathrm{O}_{2}$-treated HepG2 cells. (A) Western blot analysis of protein levels of p-Nrf2. (B) Data quantification of protein expression of Nrf2 and p-Nrf2. (C) Western blot analysis of antioxidant enzyme levels. (D) Data quantification of antioxidant enzyme/ $\beta$-actin protein expression. Values are expressed as the mean \pm standard deviation $(\mathrm{n}=3)$. ${ }^{*} \mathrm{P}<0.05$, vs. untreated control; ${ }^{~} \mathrm{P}<0.05$, vs. $5 \mathrm{mM} \mathrm{H}_{2} \mathrm{O}_{2}$-treated control; ${ }^{\# \#} \mathrm{P}<0.01$, vs. $5 \mathrm{mM} \mathrm{H}_{2} \mathrm{O}_{2}$-treated control. -, control cells without $5 \mathrm{mM} \mathrm{H}_{2} \mathrm{O}_{2}$; +, control cells treated with $5 \mathrm{mM} \mathrm{H} \mathrm{O}_{2}$; PBP2, phycobiliprotein 2; Nrf2, nuclear factor erythroid-derived 2-like 2; p-Nrf2 , phosphorylated Nrf2; CAT, catalase; SOD, superoxide dismutase; GPx, glutathione peroxidase; Con, control; AEs, antioxidant enzymes.

PBP2 upregulates the protein expression of $p$-Nrf2 and antioxidant enzymes. To examine the possible mechanisms underlying the antioxidative effect, the present study investigated the effects of $1 \mu \mathrm{g} / \mathrm{ml}$ PBP2 on the p-Nrf2/antioxidant enzyme (CAT, SOD and GPx) pathway in HepG2 cells. As shown in Fig. 4A and B, HepG2 cells exposed to $5 \mathrm{mM} \mathrm{H}_{2} \mathrm{O}_{2}$ showed a significant decrease in the level of p-Nrf2. However, a marked increase in the level of p-Nrf2 was detected in the $0.1-1 \mu \mathrm{g} / \mathrm{ml}$ PBP2-treated groups. The expression levels of CAT and GPX were not significantly affected by $5 \mathrm{mM} \mathrm{H}_{2} \mathrm{O}_{2}$, however, SOD was decreased by $5 \mathrm{mM} \mathrm{H}_{2} \mathrm{O}_{2}$ and increased by treatment with PBP2 (Fig. 4C and D). GPX was not affected by $5 \mathrm{mM} \mathrm{H} \mathrm{H}_{2}$, but was increased by the effect of PBP2, suggesting that it was used to reduce the increased ROS. This increase was not concentration-dependent in the range of $0.01-1 \mu \mathrm{g} / \mathrm{ml}$, suggesting that the removal of ROS used antioxidant enzymes other than SOD and GPX. The present study did not examine all the antioxidant enzymes and mechanisms, but confirmed the possibility. Therefore, the results of the present study may assist in elucidating the more specific mechanism of PBP2.

The results showed that treatment with $5 \mathrm{mM} \mathrm{H}_{2} \mathrm{O}_{2}$ led to decreases in the expression of p-Nrf2 and SOD, which were reversed by treatment with $0.1-1 \mu \mathrm{g} / \mathrm{ml}$ PBP2. However, no significant difference in the protein level of CAT was observed among these groups. These data suggested that PBP2 controlled $\mathrm{H}_{2} \mathrm{O}_{2}$-induced oxidative stress by regulating the expression of $\mathrm{p}-\mathrm{Nrf} 2 / \mathrm{SOD}$.

\section{Discussion}

PBPs have been described as having potent antioxidant activities and are used as pharmaceutical agents based on such reported activities $(9,10,12,13,30-32)$. In the present study, various physiological activities of PBP were isolated and identified from P. yezoensis.
PE is a hexamer in dilute acidic solutions. The monomer has two peptide chains, $\alpha$ and $\beta$, each with a molecular weight of $19.5 \mathrm{kDa}$. Therefore, the total molecular weight of the monomer is $39 \mathrm{kDa}$. PE acquires a scarlet color by binding to phycoerythrobilin, a pigment that normally has a minimal absorption spectrum of 498, 540 and $565 \mathrm{~nm}$, and, typically, two or three molecules bind with one another. Red algae contain phycoerythrobilin and phycourobilin, with a maximum absorbance of $490 \mathrm{~nm}$ and, typically, two molecules bind to the protein. Certain types of PE show different intensities in the absorption bands and have different absorption spectra; however, in the majority of cases, PE has a maximum band of fluorescence emission at $552 \mathrm{~nm}(33,34)$. In the present study, $P$. yezoensis tissue underwent a lysis protocol, resulting in the majority of protein complexes dissociating to yield proteins in only the monomer form, which were then analyzed by 2D-PAGE. As a result, two types of PE were observed at $19 \mathrm{kDa}$. However, PC- $\beta$ was not observed in the protein samples analyzed in the present study. PC in seaweed is usually a monomer with a molecular weight of $40 \mathrm{kDa}$, and is composed of an $\alpha$-chain with a molecular weight of $18.5 \mathrm{kDa}$ and $\beta$-chain with a molecular weight of $20.5 \mathrm{kDa}$, and two or three blue-colored phycocyanobilin molecules bind with one phycoerythrobilin molecule $(35,36)$. PC in red algae is the R-type with an absorption band between 615 and $620 \mathrm{~nm}$, however, certain types show an absorption band at $550 \mathrm{~nm}$, caused by phycoerythrobilin (33).

In APC, a monomer with a molecular weight of $15.5 \mathrm{kDa}$ forms a hexamer $(35,36)$. APC is less abundant than PE or PC and, like PC, has a bond between phycocyanobilin and the protein. However, it differs from PE and PC in its absorption spectrum, showing maximum absorption bands at 620 and $650 \mathrm{~nm}$ (33).

Color mutations in $P$. yezoensis yield, in addition to the wild-type, a red type, a green type and a yellow type, all of which have different types of phycobilin (37). The wild-type 
consists of R-PE and C-PC; the red type consists of R-PE and $\mathrm{R}-\mathrm{PC}$; the green type consists of B-PE and C-PC; and the yellow type consists of B-PE and R-PC. APC occurs in all these genotypes. The present study used the red-type $P$. yezoensis and its R-PE was identified in spots 5, 42, 43 and 51. However, PC could not be classified in present study. Presumably, PC was dissolved or dissociated by the reagent used in the pretreatment process for 2D-PAGE and ESI Q TOF, and thus was not classified or detected.

Marine organisms, including seaweeds, contain various chemical agents, including fatty acids, carotenoids, polysaccharides and pigment proteins, all showing diverse biological activities $(1-5,31)$. In particular, several studies have focused on the potential biochemical applications of peptides originating from marine organism-derived proteins (32). The diversity of such applications is based potentially on the essential amino acid compositions of these proteins.

In the present study, the antioxidant activity was confirmed by synthesizing the identified PBP. No cytotoxicity was observed for the 13 synthetic peptides assessed, as shown in Fig. 2C. The percentage of cells that survived oxidative stress was observed to increase when the cells were treated with the synthesized peptides. Therefore, the peptides showed no toxicity in these cell culture experiments. The intracellular ROS levels, measured with DCF-DA, increased 2-3-fold in cells treated with $\mathrm{H}_{2} \mathrm{O}_{2}$ and these values decreased when treated with certain peptides. The ROS levels were found to decrease by up to $56 \%$ in the presence of PBP2 (synthesized from PE), as shown in Fig. 2D. The ROS levels were reduced by PBP 1, 2 (synthesized from the PE $\beta$ subunit), 7-9 (synthesized from PE $\alpha$ subunit) and 10-12 (synthesized from PC), demonstrating the antioxidant properties of PE and PC. For several decades, several in vitro and in vivo studies have been performed on the potential removal of free radicals by PBPs. Sonani et al reported on external antioxidant and free radical removal activities of three types of PBP extracted from Lyngbya sp., a cyanobacterium (13). PE exhibited antioxidant activity by removing ROS through direct oxidation-reduction reactions, whereas PC and APC exhibited antioxidant activities through indirect mechanisms, including metal ion chelation. Such reports indicate that the antioxidant activities of PBPs occur by various mechanisms and the mechanism is dependent on amino acid side chains of these PBPS. Here, it was hypothesized that the distribution of the amino acids on the surface of PBPs defines their diverse antioxidant activities. The peptides synthesized from PE types of $P$. yezoensis also showed activity that reduced ROS levels. In the present study, the antioxidant activities attributed to PBPs were evaluated by synthesizing shorter peptide fragments of PBPs rather than full-length proteins in an effort to identify novel candidate peptides for experiments on antioxidant and anti-aging activities.

Amino acids with hydrophobic branch chains are good proton donors and metal ion chelation agents. Similarly, acidic, basic and aromatic amino acids facilitate the removal of metal ions (38). PBPs have been reported to be metal ion chelation agents, and thus effective at removing metals. It has been suggested that certain antioxidant activities of PBPs are attributable to proton donation or metal ion chelation, both dependent on amino acid composition $(13,39)$. In particular, it was reported that PE has low chelation capability but a high reduction capacity when compared with that of PC or APC, indicating that PE and PC may be important in oxidation-reduction reactions and, therefore, in antioxidant activities (27). The peptides synthesized from PE exhibited higher ROS removal activities compared with the peptides synthesized from PC or APC.

When oxidative stress occurs in a cell, the cell activates several processes to reduce this stress (40). One of these processes is to increase antioxidant enzyme levels through the Nrf2/antioxidant responsive element (ARE) pathway. Nrf2 enters the nucleus and converts to p-Nrf2, which activates ARE. This allows the expression of antioxidant enzymes, including CAT, SOD and GPx, and is used to eliminate oxidative stress. In the present study, PBP2 increased the expression of p-Nrf2, a typical antioxidant stress reliever. In addition, PBP2 increased the expression of antioxidant enzymes SOD and GPx. PBP2 was able to inhibit ROS production directly by increasing the activity of p-Nrf2 and SOD. The subsequent experiments corroborated these findings.

Various biomolecules with potent antioxidant activities have been examined for the prevention of aging. Aging is defined as systematic decreases in physiological functions, including biochemical functions, occurring in the majority of organisms. According to the free radical theory of aging, a major cause is activated oxygen species and, therefore, removal of such species is being investigated for the prevention of aging. The present study was performed to address whether certain peptides, derived from PBPs, with identified antioxidant activities may be useful for the prevention of aging. The findings identified several peptides as candidate antioxidant agents. The aim of the present study was to analyze the signaling pathways involved in the mechanism of action of peptides synthesized from PBPs, demonstrating their antioxidant activities in cells and addressing their potential value as antioxidant agents.

In the present study, PBPs from $P$. yezoensis were identified by proteomics and several PBP peptides were synthesized to examine their inhibition of ROS generation. Several synthesized PBPs peptides showed antioxidant activities in HepG2 cells. In particular, the PBP2 peptide was identified as a potential antioxidant as this peptide downregulated ROS, and appeared to function through the p-Nrf2/SOD pathways. In conclusion, $\mathrm{PBP} 2$ attenuated $\mathrm{H}_{2} \mathrm{O}_{2}$-induced oxidative stress in the HepG2 cells.

\section{Acknowledgements}

The authors would like to express sincere gratitude to Dr Dong-Gyun Kim and Dr Young-Ok Kim (Korean National Fisheries Science Research Institute) for helping to carry out 2D-PAGE.

\section{Funding}

This study was supported by the Basic Science Research Program through the National Research Foundation of Korea, which is funded by the Ministry of Education (grant no. 2012R1A6A1028677). 


\section{Availability of data and materials}

The datasets used and/or analyzed during the current study are available from the corresponding author on reasonable request.

\section{Authors' contributions}

The design of the experiment was done by EYK and TJN. Experimentation and drafting of the manuscript was performed by EYK. YHC assisted with revising the manuscript critically for important intellectual content.

\section{Ethics approval and consent to participate}

Not applicable.

\section{Consent for publication}

Not applicable.

\section{Competing interests}

The authors declare that they have no competing interests.

\section{References}

1. Pádua D, Rocha E, Gargiulo D and Ramos AA: Bioactive compounds from brown seaweeds: Phloroglucinol, fucoxanthin and fucoidan as promising therapeutic agents against breast cancer. Phytochem Lett 14: 91-98, 2015.

2. Pérez MJ, Falqué E and Dominguez $\mathrm{H}$ : Antimicrobial action of compounds from marine seaweed. Mar Drugs 14: e52, 2016.

3. Magalhaes KD, Costa LS, Fidelis GP, Oliveira RM, Nobre LT, Dantas-Santos N, Camara RB, Albuquerque IR, Cordeiro SL, Sabry DA, et al: Anticoagulant, antioxidant and antitumor activities of heterofucans from the seaweed Dictyopteris delicatula. Int J Mol Sci 12: 3352-3365, 2011

4. Cunha L and Grenha A: Sulfated seaweed polysaccharides as multifunctional materials in drug delivery applications. Mar Drugs 14: E42, 2016.

5. Michalak I and Chojnacka K: Algae as production systems of bioactive compounds. Eng Life Sci 15: 160-176, 2015.

6. Harnedy PA and FitzGerald RJ: Bioactive proteins, peptides, and amino acids from macroalgae(1). J Phycol 47: 218-232, 2011.

7. López-Cristoffanini C, Zapata J, Gaillard F, Potin P, Correa JA and Contreras-Porcia L: Identification of proteins involved in desiccation tolerance in the red seaweed Pyropia orbicularis (Rhodophyta, Bangiales). Proteomics 15: 3954-3968, 2015.

8. Cai C, Li C, Wu S, Wang Q, Guo Z and He P: Large scale preparation of phycobiliproteins from Porphyra yezoensis using co-precipitation with ammonium sulfate. Nat Sci 4: 536-543, 2012.

9. Jensen GS, Attridge VL, Beaman JL, Guthrie J, Ehmann A and Benson KF: Antioxidant and anti-inflammatory properties of an aqueous cyanophyta extract derived from Arthrospira platensis: Contribution to bioactivities by the non-phycocyanin aqueous fraction. J Med Food 18: 535-541, 2015.

10. Manirafasha E, Ndikubwimana T, Zeng X, Lu Y and Jing K: Phycobiliprotein: Potential microalgae derived pharmaceutical and biological reagent. Biochem Eng J 109: 282-296, 2016.

11. Hemlata and Fatma T: Screening of cyanobacteria for phycobiliproteins and effect of different environmental stress on its yield. Bull Environ Contam Toxicol 83: 509-515, 2009.

12. Reis A, Mendes A, Lobo-Fernandes H, Empis JA and Novais JM: Production, extraction and purification of phycobiliproteins from Nostoc sp. Bioresour Technol 66: 181-187, 1998.

13. Sonani RR, Singh NK, Kumar J, Thakar D and Madamwar D: Concurrent purification and antioxidant activity of phycobiliproteins from Lyngbya sp. A09DM: An antioxidant and anti-aging potential of phycoerythrin in Caenorhabditis elegans. Process Biochem 49: 1757-1766, 2014.
14. Dey A and Cederbaum AI: Alcohol and oxidative liver injury. Hepatology 43: S63-S74, 2006.

15. Loguercio $\mathrm{C}$ and Federico A: Oxidative stress in viral and alcoholic hepatitis. Free Radic Biol Med 34: 1-10, 2003.

16. Mayoral W and Lewis JH: Drug-induced liver disease. Curr Opin Gastroenterol 16: 231-238, 2000.

17. López-Terrada D, Cheung SW, Finegold MJ and Knowles BB: Hep G2 is a hepatoblastoma-derived cell line. Hum Pathol 40: $1512-1515,2009$.

18. Nowrouzi A, Meghrazi K, Golmohammadi T, Golestani A, Ahmadian S, Shafiezadeh M, Shajary Z, Khaghani S and Amiri AN: Cytotoxicity of subtoxic AgNP in human hepatoma cell line (HepG2) after long-term exposure. Iran Biomed J 14: 23-32, 2010.

19. Yook JS, Kim M, Pichiah PB, Jung SJ, Chae SW and Cha YS: The antioxidant properties and inhibitory effects on HepG2 cells of chicory cultivated using three different kinds of fertilizers in the absence and presence of pesticides. Molecules 20: 12061-12075, 2015.

20. Martín MA, Ramos S, Mateos R, Izquierdo-Pulido M, Bravo L and Goya L: Protection of human HepG2 cells against oxidative stress by the flavonoid epicatechin. Phytother Res 24: 503-509, 2010.

21. Salla S, Sunkara R, Ogutu S, Walker LT and Verghese M: Antioxidant activity of papaya seed extracts against $\mathrm{H}_{2} \mathrm{O}_{2}$ induced oxidative stress in HepG2 cells. LWT-Food Sci Tech 66: 293-297, 2016.

22. Zhao J, Ma D, Luo M, Wang W, Zhao C, Zu Y, Fu Y and Wink M: In vitro antioxidant activities and antioxidant enzyme activities in HepG2 cells and main active compounds of endophytic fungus from pigeon pea [Cajanus cajan (L.) Millsp.]. Food Res Int 56: 243-251, 2014.

23. Song JS, Kim EK, Choi YW, Oh WK and Kim YM: Hepatocyte-protective effect of nectandrin B, a nutmeg lignan, against oxidative stress: Role of Nrf2 activation through ERK phosphorylation and AMPK-dependent inhibition of GSK-3 $\beta$. Toxicol Appl Pharmacol 307: 138-149, 2016.

24. Tsai TH, Yu CH, Chang YP, Lin YT, Huang CJ, Kuo YH and Tsai PJ: Protective effect of caffeic acid derivatives on tert-butyl hydroperoxide-induced oxidative hepato-toxicity and mitochondrial dysfunction in HepG2 cells. Molecules 22: E702, 2017.

25. Martín MA, Ramos S, Mateos R, Granado Serrano AB, Izquierdo-Pulido M, Bravo L and Goya L: Protection of human HepG2 cells against oxidative stress by cocoa phenolic extract. J Agric Food Chem 56: 7765-7772, 2008.

26. Martín MA, Ramos S, Granado-Serrano AB, Rodríguez-RamiroI, Trujillo M, Bravo L and Goya L: Hydroxytyrosol induces antioxidant/detoxificant enzymes and Nrf2 translocation via extracellular regulated kinases and phosphatidylinositol-3-kinase/protein kinase B pathways in HepG2 cells. Mol Nutr Food Res 54: 956-966, 2010.

27. Sonani RR, Rastogi RP and Madamwar D: Antioxidant potential of phycobiliproteins: Role in anti-aging research. Biochem Anal Biochem 4, 2015.

28. Wessel D and Flugge UI: A method for the quantitative recovery of protein in dilute solution in the presence of detergents and lipids. Anal Biochem 138: 141-143, 1984.

29. Abu-Reidah IM, Arráez-Román D, Quirantes-Piné R, FernándezArroyo S, Segura-Carretero A and Fernández-Gutiérrez A:HPLCESI-Q-TOF-MS for a comprehensive characterization of bioactive phenolic compounds in cucumber whole fruit extract. Food Res Int 46: 108-117, 2012.

30. Sonani RR, Rastogi RP, Patel R and Madamwar D: Recent advances in production, purification and applications of phycobiliproteins. World J Biol Chem 7: 100-109, 2016.

31. Cornish ML and Garbary DJ: Antioxidants from macroalgae: Potential applications in human health and nutrition. Algae 25: 155-171, 2010.

32. Cheung RC, Ng TB and Wong JH: Marine peptides: Bioactivities and applications. Mar Drugs 13: 4006-4043, 2015.

33. Sobiechowska-Sasim M, Stoń-Egiert J and Kosakowska A: Quantitative analysis of extracted phycobilin pigments in cyanobacteria-an assessment of spectrophotometric and spectrofluorometric methods. J Appl Phycol 26: 2065-2074, 2014.

34. Galland-Irmouli AV, Pons L, Luçon M, Villaume C, Mrabet NT, Guéant JL and Fleurence J: One-step purification of R-phycoerythrin from the red macroalga Palmaria palmata using preparative polyacrylamide gel electrophoresis. J Chromatogr B Biomed Sci Appl 739: 117-123, 2000 
35. Wang L, Qu Y, Fu X, Zhao M, Wang S and Sun L: Isolation, purification and properties of an R-phycocyanin from the phycobilisomes of a marine red macroalga Polysiphonia urceolata. PLoS One 9: e87833, 2014.

36. Wang Y, Gong X, Wang S, Chen L and Sun L: Separation of native allophycocyanin and R-phycocyanin from marine red macroalga Polysiphonia urceolata by the polyacrylamide gel electrophoresis performed in novel buffer system. PLoS One 9: e106369, 2014.

37. Hwang MS, Kim SO, Lee YS, Park EJ, Kim SC, Ha DS, Gong YG, Baek $\mathbf{J}$ and Choi HG: Isolation and characterization of pure lines of pigmentation and morphological mutants in Porphyra tenera Kjellman (Bangiales, Rhodophyta). Kor J Fish Aquat Sci. Doi, 2010.

38. Khantaphant S, Benjakul S and Ghomi MR: The effects of pretreatments on antioxidative activities of protein hydrolysate from the muscle of brownstripe red snapper (Lutjanus vitta). LWT-Food Sci Technol 4: 1139-1148, 2011.
39. Sarmadi BH and Ismail A: Antioxidative peptides from food proteins: A review. Peptides 31: 1949-1956, 2010.

40. Kensler TW, Wakabayashi N and Biswal S: Cell survival responses to environmental stresses via the Keap1-Nrf2-ARE pathway. Annu Rev Pharmacol Toxicol 47: 89-116, 2007.

This work is licensed under a Creative Commons Attribution-NonCommercial-NoDerivatives 4.0 International (CC BY-NC-ND 4.0) License. 